\title{
Localization of ribosomal genes in three Pimelodus species (Siluriformes, Pimelodidae) of the São Francisco River: 5 S genes as species markers and conservation of the 18S rDNA sites
}

\author{
Caroline Garcia $^{1}$ and Orlando Moreira Filho ${ }^{2}$ \\ ${ }^{1}$ Departamento de Genética e Biologia Evolutiva, Universidade de São Paulo, São Paulo, SP, Brazil. \\ ${ }^{2}$ Departamento de Genética e Evolução, Universidade Federal de São Carlos, São Carlos, SP, Brazil.
}

\begin{abstract}
Pimelodidae is one of the most representative of Neotropical catfish families. However, these fish are still poorly studied in terms of cytogenetics, especially regarding the application of more accurate techniques such as the chromosomal localization of ribosomal genes. In the present work, fluorescent in situ hybridization with 5S and 18S rDNA probes was employed for rDNA site mapping in Pimelodus sp., P. fur and P. maculatus from the São Francisco River in the Três Marias municipality - MG. The results from the application of the $18 \mathrm{~S}$ probe confirmed the previous data obtained by silver nitrate staining, identifying a simple nucleolar organizing region system for these species. However, the labeling results from the 5S rDNA probe demonstrated a difference in the number and localization of these sites between the analyzed species. The obtained data allowed inferences on the possible processes involved in the karyotypic evolution of this genus.
\end{abstract}

Key words: Pimelodus, paracentric inversion, 5S rDNA, 18S rDNA, species marker.

Received: August 21, 2006; Accepted: May 11, 2007.

In higher eukaryotes, rDNA is organized into two distinct families: the large, $45 \mathrm{~S}(18 \mathrm{~S}, 28 \mathrm{~S}$ and $5,8 \mathrm{~S})$ and the small, 5S (Pendas et al., 1994), both formed by multiple tandemly organized copies. In contrast to the $45 \mathrm{~S}$ rDNA which may also be localized by other techniques such as silver nitrate and $\mathrm{GC}$-specific fluorochrome staining, 5S rDNA sites may only be visualized through in situ hybridization (Ferro et al., 2001).

Little is known of the chromosome localization of the ribosomal genes in Neotropical fish, especially in relation to 5S rDNA (Martins and Galetti Jr., 1999). Even so, the few available data have shown that these sites may constitute an important cytotaxonomical marker in this group.

Pimelodidae, one of the largest Neotropical catfish families (Pinna, 1998). It is marked by a pronounced karyotypic variability with a predominance of $2 \mathrm{n}=56$ chromosomes (Swarça et al., 2000). Nevertheless, only few studies report the application of more accurate cytogenetic techniques, such as in situ hybridization, in this group (Swarça et al., 2001a, b; Souza et al., 2004).

The localization of the 5S and 18S rDNA genes in three sympatric and syntopic Pimelodus species found in

Send correspondence to Caroline Garcia. Departamento de Genética e Biologia Evolutiva, Universidade de São Paulo, Rua do Matão 277, Edifício André Dreyfus, Cidade Universitária, 05508-090 São Paulo, SP, Brazil. E-mail: carol99bio@yahoo.com. the São Francisco River is reported in the present work in an attempt to identify possible markers regarding localization and number of rDNA clusters, as well to confirm data concerning the nucleolar organizing regions (Ag-NORs) previously described by Garcia and Moreira-Filho (2005).

Specimens from three species belonging to the genus Pimelodus were analyzed: Pimelodus sp. (15 females, 10 males), $P$. fur (10 females, 3 males) and P. maculatus (10 females, 6 males), from the São Francisco River in the Três Marias municipality - MG, Brazil. The preparation of mitotic chromosomes was obtained from kidney cells through the direct preparation technique adapted by Bertollo et al. (1978) for fish studies. Chromosome morphology was determined according to the arm ratio proposed by Levan et al. (1964). The fundamental number (FN) was calculated considering metacentric $(\mathrm{m})$, submetacentric $(\mathrm{sm})$ and subtelocentric (st) chromosomes as bearers of two arms, and acrocentric (a) chromosomes as bearers of a single arm. Fluorescent in situ hybridization (FISH) followed the protocol described by Pinkel et al. (1986) using 18S (Hatanaka and Galetti Jr., 2004) and 5S rDNA probes (Martins and Galetti Jr., 1999).

Through the karyotypic analyses it was possible to verify that the three studied species differed in their diploid number and chromosome constitution with $P$. fur presenting $2 \mathrm{n}=54$ and a karyotypic formula of $32 \mathrm{~m}+8 \mathrm{sm}+6 \mathrm{st}+$ 
$8 \mathrm{a}$, with an $\mathrm{FN}=100$ (Figure 1a). In P. maculatus, the $2 \mathrm{n}=56$ was distributed into $32 \mathrm{~m}+12 \mathrm{sm}+12 \mathrm{st}$ with an $\mathrm{FN}=112$ (Figure 1b). Pimelodus sp. also presented $2 \mathrm{n}=56$ with the karyotype being composed of $32 \mathrm{~m}+12 \mathrm{sm}+6 \mathrm{st}+$ 6a with a FN $=106$ (Figure 1c).

The application of the $18 \mathrm{~S}$ rDNA probe resulted in a pair of fluorescent signals located in the terminal portion of the long arm of chromosome pair 20 in the three species analyzed. In $P$. fur a size heteromorphism involving hybridization signals between the homologues could be observed in these chromosomes (Figure 2 - boxes).

FISH with the 5S rDNA probe demonstrated that these ribosomal sites vary in position and number (4 to 6) in the Pimelodus species analyzed (Figures 1 and 2). The occurrence of a pair of fluorescent signals interstitially located in the long arm of the first chromosome was observed for the three species; however in $P$. fur these sites were relatively smaller, hindering their observation. Another pair of signals was also observed in a pericentromeric position of the long arm of chromosome pair 17 in P. fur and Pimelodus sp., while in P. maculatus these markings were located in a terminal position of the same chromosome pair. Besides these sites, the existence of a third pair of markings was observed in Pimelodus sp. and P. maculatus.. It was located in a pericentromeric position of the long arm of the $21^{\text {st }}$ chromosome pair.

Previous cytogenetic studies performed by Garcia and Moreira-Filho (2005) involving the species here analyzed suggested the existence of a simple NOR system, based on data obtained from silver nitrate and chromomycin $\mathrm{A}_{3}$ staining,. The results of the present work obtained by FISH using a $18 \mathrm{~S}$ rDNA probe confirm this hypothesis, as well as the occurrence of a size heteromorphism involving the NOR region in $P$. fur. This is possibly related to the different number of copies of these genes in the homologues resulting from an unequal crossover or some other kind of chromosomal rearrangement

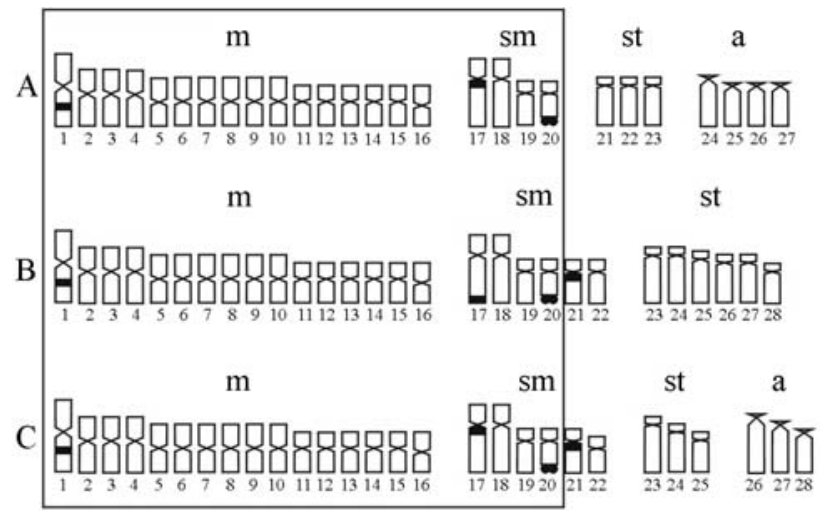

Figure 1 - Idiogram representative of the chromosome set in A) P. fur, B) P. maculatus and C) Pimelodus sp.. The dark circles correspond to nucleolar organizing regions and the shaded regions to the $5 \mathrm{~S}$ rDNA gene localizations. Highlighted is the part of the chromosome set macroscopically similar in the three analyzed species.

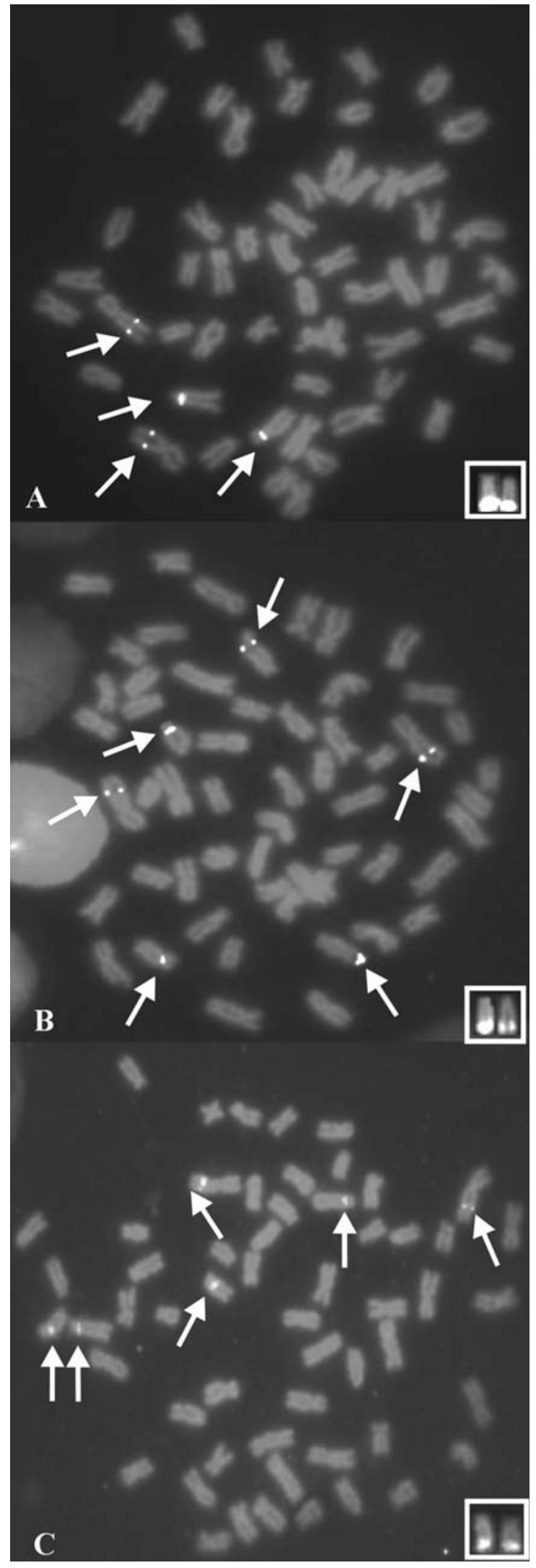

Figure 2 - Metaphases in A) P. fur, B) P. maculatus and C) Pimelodus sp., submitted to FISH with a $5 \mathrm{~S}$ rDNA probe. The arrows indicate the fluorescent signals. In detail, the nucleolar organizing chromosomes identified through FISH with an 18S rDNA probe. 
(Foresti et al., 1981). The occurrence of simple NORs and size heteromorphisms involving this region have already been confirmed by FISH with an $18 \mathrm{~S}$ probe in other Pimelodus species (Souza et al, 2004). These data reinforce the idea that the occurrence of a terminal simple NOR system is a conserved characteristic for the genus.

Pimelodus sp. and P. maculatus are karyotypically similar in relation to diploid number, NOR number and position and number of $5 \mathrm{~S}$ rDNA sites. Despite this, a few differences were observed, such as the localization of the $5 \mathrm{~S}$ rDNA gene in the $17^{\text {th }}$ chromosome pair. This localization difference indicates that a probable paracentric inversion, or even a transposition event, occurred in P. maculatus, resulting in the transportation of these genes from a pericentromeric position to a terminal position.

In $P$. fur, a reduction in the diploid number and in the number of 5S rDNA sites (only two pairs) and a differential intensity of the markings in the first chromosome pair were observed. The absence of markings in pair 21 could derive from deletions or possible processes that resulted in the reduction in chromosome number. The intensity difference of the fluorescent signal involving these regions after FISH could be explained by the existence of a smaller number of copies of the 5S rDNA genes in this species.

In the present work, the predominance of $5 \mathrm{~S}$ rDNA clusters in an interstitial or pericentromeric position was observed. According to Martins and Galetti Jr. (1999), the localization of these sites in an interstitial position would be related to a higher degree of protection of these sequences, avoiding transposition and crossing events that are more frequent in more terminal positions.

Among the Siluriformes, there are few available data on the localization of $5 \mathrm{~S}$ genes. Previous studies involve members of the families Loricariidae (Kavalco et al., 2004) and Heptapteridae (Garcia et al., 2003), and demonstrate the predominance of only a single chromosome pair bearing the $5 \mathrm{~S}$ ribosomal sites located in an interstitial position. In Hypostomus and Upsilodus a greater number of sites were identified, eight and four, respectively (Kavalco et al., 2004). The few cytogenetic studies performed in the genus Pimelodus do not allow the discussion of whether the presence of up to six 5S rDNA sites is a plesiomorphic or apomorphic characteristic and the localization difference demonstrate that the identification of these sites for these Pimelodus species from the São Francisco River may be considered a species marker.

The data here gathered indicate a high degree of conservation involving the NOR region in terms of number and position in the three analyzed Pimelodus species. Another characteristic that indicates a strong evolutionary relationship between these species is the conservation of the karyotypic macrostructure of the 20 first chromosome pairs and the differences that appeared regarding numerical and structural terms in the remaining karyotype (Figure 1). These could easily be explained by the occurrence of non-
Robertsonian rearrangements where the inversions stand out and explain, for example, the difference in the localization of the 5S rDNA genes in the $17^{\text {th }}$ chromosome pair of $P$. maculatus, indicating that these rearrangements could have had a major importance in the karyotypic evolution of the genus.

\section{Acknowledgments}

The authors thank Dr. Yoshimi Sato, CODEVASF, for the aid in the sample collections. This work was financially supported by the Fundação de Amparo à Pesquisa do Estado de São Paulo (FAPESP - Proc. 02/10516-0) and the Conselho Nacional de Desenvolvimento Científico e Tecnológico (CNPq) (Proc. 473313/03-0).

\section{References}

Bertollo LAC, Takahashi CS and Moreira-Filho O (1978) Cytotaxonomic considerations on Hoplias lacerdae (Pisces, Erythrinidae). Braz J Genet 1:103-120.

Ferro DAM, Neo DM, Moreira Filho O and Bertollo LAC (2001) Nucleolar organizing regions, $18 \mathrm{~S}$ and 5S rDNA in Astyanax scabripinnis (Pisces, Characidae): Populations distribution and functional diversity. Genetica 110:55-62.

Foresti F, Almeida-Toledo LF and Toledo-Filho AS (1981) Polymorphic nature of nucleolus organizer regions in fishes. Cytogenet Cell Genet 31:137-144.

Garcia C and Moreira Filho O (2005) Cytogenetical analyses in three fish species of the genus Pimelodus (Siluriformes, Pimelodidae) from rio São Francisco: Considerations about the karyotypical evolution in the genus. Neotrop Ichthyol 3:285-290.

Garcia C, Moreira Filho O, Bertollo LAC and Centofante L (2003) B chromosomes and natural triploidy in Rhamdia sp. (Pisces, Siluriformes, Heptapteridae). Cytologia 64:403411.

Hatanaka T and Galetti Jr. PM (2004) Mapping of the 18S and 5S ribosomal RNA genes in the fish Prochilodus argenteus Agassiz 1829 (Characiformes, Prochilodintidae). Genetica 122:239-244.

Kavalco KF, Pazza R, Bertollo LAC and Moreira-Filho O (2004) Gene mapping of $5 \mathrm{~S}$ rDNA sites in eight fish species from the Paraíba do Sul river Basin, Brazil. Cytogenet Genome Res 106:107-110.

Levan A, Fredga K and Sandberg HA (1964) Nomenclature for centromeric position on chromosomes. Heretidas 52:201220.

Martins C and Galetti Jr PM (1999) Chromosomal localization of 5S rDNA genes in Leporinus fish (Anastomidae, Characiformes). Chrom Res 7:363-367.

Pendás AM, Morán P, Freije JP and Garcia-Vazquez E (1994) Chromossomal mapping and nucleotide sequence of two tandem repeats of Atlantic Salmo 5S rDNA. Cytogenet Cell Genet 67:31-36.

Pinkel D, Straume T and Gray J W (1986) Cytogenetic analysis using quantitative, high-sensitivity, fluorescence hybridization. Proc Natl Acad Sci USA 83:2934-2938.

Pinna MCC (1998) Phylogenetic relationships of Neotropical Siluriformes: Historical overview and synthesis of hypothe- 
sis. In: Malabarba LR, Reis RE, Vari RP, Lucena ZM and Lucena CAS (eds) Phylogeny and Classification of Neotropical Fishes. Edipurcs, Porto Alegre, pp 279-330.

Souza L, Swarça AC and Dias AL (2004) Analyses of the nucleolus organizer region in 5 species of the genus Pimelodus (Siluriformes, Pimelodidae) using $\mathrm{AgNO}_{3}, \mathrm{CMA}_{3}$ and FISH with the 18S rDNA probe. Caryologia 57:145-151.

Swarça AC, Giuliano-Caetano L and Dias AL (2000) Cytogenetics of species of the families Pimelodidae e Rhamdiidae (Siluriformes). Genet Mol Biol 23:589-593.
Swarça AL, Cestari MM, Giuliano-Caetano L and Dias AL (2001a) Cytogenetic characterization of the large South American siluriform fish species Zungaro zungaro (Pisces, Pimelodidae). Chrom Science 5:51-55.

Swarça AC, Giuliano-Caetano L, Vanzela ALL and Dias AL (2001b) Heteromorphism of rDNA size in Pirinampus pirinampu (Pisces, Pimelodidae) detected by in situ hibridization. Cytologia 66:275-278.

Associate Editor: Lurdes Foresti de Almeida-Toledo

License information: This is an open-access article distributed under the terms of the Creative Commons Attribution License, which permits unrestricted use, distribution, and reproduction in any medium, provided the original work is properly cited. 